\title{
GAMBARAN KERASIONALAN PENGOBATAN PADA PASIEN DEMAM BERDARAH DENGUE DI RUANG RAWAT INAP RSI SITI KHADIJAH PALEMBANG TAHUN 2017
}

\author{
Yunilda Rosa ${ }^{1}$, Masnir Alwi ${ }^{2}$, Monica Julianti ${ }^{3}$ \\ 1,2. Dosen STIK Siti Khadijah Palembang \\ Email.yunildarosa2018@gmail.com
}

\begin{abstract}
ABSTRAK
Kasus penyakit demam berdarah dengue (DBD) merupakan salah satu masalah kesehatan didunia karena prevalensinnya yang cenderung meningkat, sehingga perlu adanya ketepatan terapi untuk menekan angka kesakitan. Salah satu aspek yang berkaitan dengan hal tersebut adalah rasionalitas pengobatan, Penelitian ini bertujuan untuk memperoleh gambaran rasionalitas pengobatan pasa pasien demam berdarah dengue (DBD) di Rumah Sakit Islam Siti Khadijah Palembang Tahun 2017. Penelitian ini merupakan jenis penelitian non eksperimen. Subyek penelitian adalah seluruh pasien rawat inap yang terdiagnosa utama demam berdarah dengue di Rumah Sakit Islam Siti Khadijah Palembang Tahun 2017. Bahan penelitian ini yaitu data rekam medik, data yang digunakan merupakan data retrospektif yang diambil dengan menggunakan teknik purposive sampling. Data yang didapat sebanyak 30 responden yang memenuhi kriteria inklusi-eksklusi. Analisis data yang digunakan adalah analisis univariate. Hasil penelitian didapatkan bahwa terdapat ketidaktepatan dosis sebesar (6,66\%). Gambaran kerasionalan pengobatan yang dilakukan dari 30 pasien menyatakan bahwa rasional pengobatan sebesar $(93,33 \%)$ dan ketidakrasionalan pengobatan sebesar $(6,66 \%)$. Disarankan adanya upaya peningkatan kepatuhan bagi tenaga profesi kesehatan di rumah sakit dalam hal kelengkapan pencatatan dalam rekam medik.
\end{abstract}

Kata Kunci : $\quad$ Demam Berdarah Dengue, Rasionalitas Pengobatan, Pola Penggobatan.

\begin{abstract}
The case of dengue fever (DF) is one of the health problems in the world which its prevalence increased hence the accuracy of therapy is needed to reduce morbidity. One one aspects that related to this is rationality treatment. This study aims to obtain an overview of rationality treatment in patients who suffered dengue fever (DF) in the Islamic Hospital Siti Khadijah Palembang in 2017. This research is a non-experimental research. The research subjects were all the patients who were diagnosed with dengue fever at the Siti Khadijah Islamic Hospital Palembang in 2017. The data was take based on medical record, the used data were retrospective data which were taken by using purposive sampling technique. The obtained data were 30 respondents who met the inclusion-exclusion criteria. The data analysis used is univariate analysis. The result showed that there was an inaccurate dose of (6.66\%). A description of the rationality of treatment carried out from 30 patient stated that treatment rationality was $(93,33 \%)$ and treatment irrationality was $(6,66 \%)$. It is suggested that efforts be made to increase compliance for health professionals in hospitals in the completeness of recording in medical records.
\end{abstract}

\footnotetext{
KeyWords : $\quad$ Dengue Fever, Rationality Treatment, Pattern of Treatment

Pendahuluan Health Organization (WHO) tahun 2011

Penyakit demam berdarah dengue (DBD) menyatakan, 2,5 milyar penduduk (sekitar $2 / 5$ dari populasi penduduk dunia di negara tropis dan subtropis) sangat berisiko terinfeksi DBD.

Target rencana strategi Kementerian sampai saat ini merupakan salah satu masalah kesehatan di dunia karena prevalensinya yang cenderung meningkat serta penyebarannya yang semakin luas (WHO, 2011). Data dari World Kesehatan untuk angka kesakitan DBD tahun 2014 sebesar $<35$ per 100.000 penduduk. Pada
} 
tahun 2012 terdapat 5 provinsi yang memiliki CFR akibat DBD tinggi $(>2 \%)$ yaitu Provinsi Papua Barat, Maluku, Gorontalo, Kep. Bangka Belitung, dan Jambi. Hal ini menunjukkan bahwa masih perlu upaya peningkatan kualitas pelayanan kesehatan, manajemen tata laksana penderita di sarana-sarana pelayanan kesehatan, peningkatan kualitas dan kuantitas SDM kesehatan di rumah sakit dan puskesmas (dokter, perawat dan lain-lain) termasuk peningkatan sarana-sarana penunjang diagnostik dan penatalaksanaan bagi penderita di saranasarana pelayanan kesehatan (Kemenkes RI, 2013).

Berdasarkan data Dinas Kesehatan Sumatera Selatan kasus demam berdarah di Sumatera Selatan pada tahun 2014 sebanyak 1.143, pada tahun 2015 sebanyak 1.721 kasus dan pada tahun 2016 mengalami peningkatan sebanyak 3.243 kasus (Dinkes Sumsel, 2016).

Berdasarkan data dari Dinas Kesehatan Kota Palembang angka kejadian demam berdarah di kota Palembang pada tahun 2014 sebanyak 875 kasus, pada tahun 2015 sebanyak 1.223 kasus dan pada tahun 2016 mengalami peningkatan sebanyak 1.883 kasus (Dinkes Kota Palembang, 2016).

Berdasarkan data rekam medik Rumah Sakit Islam Siti Khadijah, didapatkan angka kejadian DBD pada tahun 2014 sebanyak 339 kasus, pada tahun 2015 sebanyak 309 kasus dan pada tahun 2017 sebanyak 276 kasus.

Kasus DBD cenderung meningkat pada musim hujan, kemungkinan disebabkan oleh beberapa faktor diantaranya: perubahan musim mempengaruhi frekuensi gigitan nyamuk, karena pengaruh musim hujan, puncak jumlah gigitan terjadi pada pagi dan sore hari, perubahan musim mempengaruhi manusia sendiri dalam sikapnya, misalnya dengan lebih banyak berdiam di rumah selama musim hujan (Hendarwanto, 2014).

Daerah yang terjangkit DBD pada umumnya adalah kota atau wilayah yang padat penduduknya, rumah yang saling berdekatan memudahkan penularan penyakit ini. Mengingat nyamuk aedes aegypty terbangnya maksimal 100 meter. Di Indonesia penduduknya makin bertambah dan transportasi semakin baik serta perilaku masyarakat dalam menampung air, penampungan air ini sangat rawan sebagai tempat berkembangnya nyamuk aedes aegypty dan virus dengue karena nyamuk aedes aegypty hidup di air bersih. (Nadesul, 2015).

Pengobatan terhadap virus dengue sampai sekarang bersifat penunjang agar pada pasien dapat bertahan hidup. Pengobatan yang diberikan biasanya bersifat penurun demam dan menghilangkan rasa sakit pada otot-otot atau sendi-sendi selain harus istirahat mutlak dan banyak minum. . Pada DBD, terapi dengan antipiretik harus diberikan pada pada pasien dengan hiperpireksia, terutama bagi yang mempunyai riwayat kejang dan demam. Untuk itu perlu dipertimbangkan pemberian antipiretik yang aman untuk anak. Dari berbagai standar yang ada, menyebutkan bahwa dalam tatalaksana DBD pemberian obat antipiretik merupakan pilihan yang aman dan tepat untuk obat turun panas dan analgesik pada anak-anak adalah parasetamol (Kemenkes RI, 2014).

\section{Tujuan Penelitian}

Diperolehnya gambaran tentang rasionalitas pengobatan dalam terapi demam berdarah diruang rawat inap Rumah Sakit Islam Siti Khadijah Palembang Tahun 2017.

\section{Metodologi Penelitian}

Jenis penelitian ini menggunakan penelitian non-eksperimental yaitu penelitian dengan pengambilan data tanpa perlakuan terhadap subyek uji. Rancangan yang digunakan adalah gambaran deskriptif untuk mengetahui gambaran pengobatan pada pasien demam berdarah dengue. Populasi penelitian ini adalah semua pasien demam berdarah dengue yang tercatat di rekam medik Rumah Sakit Islam Siti Khadijah Palembang Tahun 2017 yang berjumlah 30 pasien. Sampel adalah sebagian dari jumlah yang diambil dari keseluruhan objek yang diteliti dan dianggap mewakili seluruh populasi (Notoatmodjo 2014). Sampel yang digunakan adalah sebagian pasien demam berdarah dengue yang tercatat di rekam medik Rumah Sakit Islam Siti Khadijah Palembang Tahun 2017, yang berjumlah 30 orang. Teknik pengambilan sampel dalam penelitian ini adalah Purposive Sampling. Purposive Sampling yang didasarkan pada suatu pertimbangan tertentu yang dibuat oleh peneliti sendiri, berdasarkan ciri pasien anak-anak yang berusia 1-12 tahun yang terdiagnosis demam berdarah dengue. Dalam penelitian ini analisis data menggunakan analisis univariate. Analisis univariat adalah cara analisis dengan mendeskripsikan atau menggambarkan data yang telah terkumpul sebagaimana adanya tanpa membuat kesimpulan yang berlaku untuk umum atau generalisasi.

\section{Hasil dan Pembahasan}

\section{Hasil Penelitian}

Tabel 1 Distribusi Tepat Diagnosis pada Pasien yang Terkena DBD di Ruang Rawat Inap RSI Siti Khadijah Palembang 


\begin{tabular}{lcc}
\hline \multicolumn{1}{c}{ Tepat Diagnosis } & Jumlah & $\begin{array}{c}\text { Persentase } \\
(\%)\end{array}$ \\
\hline Tepat & 30 & $100 \%$ \\
Tidak Tepat & 0 & $0 \%$ \\
\hline \multicolumn{1}{c}{ Total } & 30 & $100 \%$ \\
\hline
\end{tabular}

Tepat diagnosis adalah penetuan jenis penyakit yang didasarkan pada keluhan pasien, keadaan pasien dan hasil laboratorium. Dikatakan tepat diagnosis jika keluhan dan hasil laboratorium sesuai dengan diagnosis yang ditegakkan. Pada penelitian ini data yang didapat dari catatan rekam medik menunjukkan semua pasien mengalami DBD. Hal ini dapat dilihat pada tabel 4.1 dimana diagnosis yang dinyatakan adalah sebesar $100 \%$ atau bisa dikatakan semua diagnosis telah tepat. Keluhan yang biasa terjadi pada kasus DBD adalah demam tinggi dan rendahnya trombosit serta hematoktrit.

Tepat diagnosis adalah penentuan jenis penyakit yang didasarkan pada keluhan pasien, keadaan pasien dan hasil laboratorium. Dikatakan tepat diagnosis jika keluhan dan hasil laboratorium sesuai dengan diagnosis yang ditegakkan. (Kemenkes, 2011).

Tidak Ada penelitian terkait, karena belum ada penelitian yang sama yang pernah dilakukan dirumah sakit.

Berdasarkan hasil penelitian dan teori, maka asumsi peneliti bahwa semua diagnosis dilakukan secara tepat (tepat 100\%).

Tabel 2. Distribusi Tepat Indikasi Penyakit pada Pasien yang Terkena DBD di Ruang Rawat Inap RSI Siti Khadijah Palembang

\begin{tabular}{ccc}
\hline $\begin{array}{c}\text { Tepat Indikasi } \\
\text { Penyakit }\end{array}$ & Jumlah & $\begin{array}{c}\text { Persentase } \\
(\%)\end{array}$ \\
\hline Tepat & 30 & $100 \%$ \\
Tidak Tepat & 0 & $0 \%$ \\
\hline Total & 30 & $100 \%$ \\
\hline
\end{tabular}

Tepat indikasi penyakit adalah pemberian obat dengan indikasi yang di lihat dari keluhan (diagnosis) penyakit. Diagnosis penyakit pada penelitian ini yaitu DBD yang tercantum dalam catatan rekam medik. Dikatakan tidak tepat indikasi jika pasien diberikan obat yang tidak sesuai dengan keluhan. Berdasarkan tabel 4.2 dapat dilihat ketepatan indikasi di Rumah Sakit Islam Siti Khadijah Palembang tahun 2017 sebanyak 40 orang (100\%). Berdasarkan 30 pasien yang telah dianalisis seluruhnya masuk kedalam pasien yang terdiagnosa DBD karena mengalami demam panas tinggi yang mendadak dan turunnya trombosit.
Menurut Kemenkes RI (2014), tepat indikasi penyakit merupakan setiap obat memiliki spektrum terapi yang spesifik. Antibiotik, misalnya di indikasikan untuk infeksi bakteri. Dengan demikian, pemberian obat ini hanya di anjurkan untuk pasien yang mempunyai gejala adanya infeksi bakteri.

Penelitian yang dilakukan oleh Akhmad (2016), tentang evaluasi penggunaan obat pada pasien demam berdarah dengue di RSUD DR. H. Abdul Moeloek Bandar Lampung, didapatkan hasil gambaran karakteristik pasien berupa jenis kelamin yang paling banyak terinfeksi DBD yaitu perempuan $56,16 \%$, usia yang paling banyak terinfeksi usia 15-44 tahun $64,38 \%$, diagnosis penyerta terbanyak adalah demam tifoid 18 kasus dari 28 kasus pasien dengan penyakit penyerta. Pola penggunaan obat DBD terbanyak yaitu analgetik-antipiretik $97,26 \%$, bentuk sediaan terbanyak adalah infus dan rute pemberian terbanyak adalah injeksi. Evaluasi rasionalitas penggunaan obat yang dilakukan yaitu ketepatan indikasi 55,38\%, ketepatan pasien $84,62 \%$, ketepatan obat meliputi ketepatan penggunaan analagetikantipiretik 100\%, penggunaan antibiotik $67,19 \%$.

Berdasarkan hal di atas, maka peneliti berasumsi bahwa pemberian obat yang sesuai dengan indikasi berarti obat yang digunakan telah sesuai dengan gejala dan diagnosis yang ada. Berdasarkan data yang diperoleh, menunjukkan sebagian besar responden hasil tepat indikasi. Hal ini disebabkan karena semua data yang ada menunjukkan bahwa suhu tubuh lebih dari $37^{\circ} \mathrm{C}$. Suhu normal anak adalah sekitar $37^{\circ} \mathrm{C}$. Pada pasien DBD, suhu biasanya tinggi dan terus berlanjut selama 2-7 hari. Setelah pasien pulang suhu tubuh harus dijaga dibawah $39^{\circ} \mathrm{C}$, jika suhu tubuh melebihi $39^{\circ} \mathrm{C}$ maka diberikan parasetamol. Evaluasi penggunaan untuk tepat indikasi tidak dapat dinilai karena tidak adanya data yang mencantumkan gejala lain selain suhu tubuh.

Berdasarkan hasil penelitian dan teori, maka asumsi peneliti bahwa semua indikasi dilakukan secara tepat (tepat 100\%).

Tabel 3. Distribusi Tepat Pemilihan Obat pada Pasien yang Terkena DBD di Ruang Rawat Inap RSI Siti Khadijah Palembang

\begin{tabular}{|c|c|c|}
\hline Tepat Pemilihan Obat & Jumlah & $\begin{array}{c}\text { Persentase } \\
(\%)\end{array}$ \\
\hline Tepat & 30 & $100 \%$ \\
\hline Tidak Tepat & 0 & $0 \%$ \\
\hline Total & 30 & $100 \%$ \\
\hline
\end{tabular}

Tepat pemilihan obat adalah terapi yang diberikan setelah diagnosis ditegakkan dengan benar oleh dokter. Obat harus memiliki efek terapi sesuai dengan spektrum penyakit. 
Berdasarkan tabel 4.3 dapat di lihat ketepatan pemilihan obat sebanyak 30 orang $(100 \%)$. Dimana pemilihan obat ini dilihat dari keluhan dan obat yang diberikan.

Menurut Kemenkes RI (2011), Keputusan untuk melakukan upaya terapi diambil setelah diagnosis ditegakkan dengan benar. Dengan demikian, obat yang dipilih harus yang memiliki efek terapi sesuai dengan spektrum penyakit.

Tidak Ada penelitian terkait, karena belum ada penelitian yang sama yang pernah dilakukan dirumah sakit.

Berdasarkan hasil penelitian dan teori, maka asumsi peneliti bahwa semua pemilihan obat dilakukan secara tepat (tepat 100\%).

Tabel 4. Distribusi Tepat Dosis pada Pasien yang Terkena DBD di Ruang Rawat Inap RSI Siti Khadijah Palembang

\begin{tabular}{|c|c|c|}
\hline Tepat Dosis & Jumlah & $\begin{array}{c}\text { Persentase } \\
(\%)\end{array}$ \\
\hline Tepat & 28 & $93,33 \%$ \\
\hline Tidak Tepat & 2 & $6,66 \%$ \\
\hline Total & 30 & $100 \%$ \\
\hline
\end{tabular}

Tepat dosis adalah kesesuaian dosis obat yang di berikan sesuai range terapi pada pasien. Berdasarkan tabel 4.4 terdapat ketidaktepatan dosis (93\%), dimana pada pemberian obat antibiotik cefixime yang diberikan terlalu rendah. Antibiotik cefixime harusnya diberikan 1x8mg untuk satu kali pakai tetapi pada pemberian yang tercantum hanya diberikan $1 \mathrm{x} 4 \mathrm{mg}$, jadi dosis yang diberikan terlalu rendah atau underdoses.

Menurut Kemenkes RI (2011), dosis obat yang digunakan harus sesuai range terapi obat tersebut. Obat mempunyai karakteristik farmakodinamik maupun farmakokinetik yang akan mempengaruhi kadar obat di dalam darah dan efek terapi obat. Dosis juga harus disesuaikan dengan kondisi pasien dari segi usia, bobot badan, maupun kelainan tertentu.

Dari hasil penelitian yang dilakukan didapatkan responden yang tepat dosis sebanyak 28 responden (93,3\%), lebih banyak jika dibandingkan dengan reponden yang tidak tepat dosis yaitu sebanyak 2 responden $(6,6 \%)$.

Menurut Kemenkes RI (2011), dosis, cara dan lama pemberian obat sangat berpengaruh terhadap efek terapi obat. Pemberian dosis yang berlebihan, khususnya untuk obat yang dengan rentang terapi yang sempit, akan sangat beresiko timbulnya efek samping. Sebaliknya dosis yang terlalu kecil tidak akan menjamin tercapainya kadar terapi yang diharapkan.

Penelitian yang dilakukan oleh Sutiawati (2016), tentang evaluasi rasionalitas penggunaan obat pada pasien DHF (Dengue Hemorrhagic Fever) ditinjau dari penggunaan antibiotik di Rumkital (Rumah Sakit Angkatan
Laut) DR. Mintohardjo Jakarta Pusat, didapatkan hasil penelitian ini dengan total jumlah 76 sampel terdiri dari 52 sampel pasien Dengue Hemorrhagic Fever (DHF) yang masuk kriteria inklusi dengan jumlah 26 pasien diberikan antibiotik dan jumlah 26 pasien tidak diberikan antibiotik serta jumlah 24 data dengan kriteria ekslusi. Dari 52 pasien DHF yang menjalani Rawat Inap di Rumah Sakit Angkatan Laut (RUMKITAL) Dr. Mintohardjo lebih banyak ditemukan jenis kelamin perempuan dengan usia berkisar antara 1-14 tahun. Penggunaan obat antibiotik yang paling banyak adalah golongan sefalosporin dan ceftriaxone. Terdapat pemberian obat antibiotik pada pasien Dengue Hemorrhagic Fever (DHF) yaitu tidak tepat indikasi, tidak tepat obat dan tidak tepat dosis sebanyak 12 pasien $(46,15 \%)$ dari 26 pasien. Untuk ketepatan pasien tidak bisa disimpulkan karena data yang didapat kurang lengkap.

Berdasarkan keterangan di atas, maka peneliti berasumsi bahwa didapatkan sebanyak 6 responden yang mengalami regimen dosis tidak tepat. Dalam penelitian ini, untuk antibiotik cefixime diberikan dosis $1 \times 4 \mathrm{mg}$ untuk (7 tahun) dan dosis $3 \times 1$ kapsul (11 tahun) pada kelompok umur 1-14 tahun. Disini, dosis $1 \times 1$ kapsul yang diberikan untuk pasien pada kelompok umur 1-14 tahun dengan berat badan $25 \mathrm{~kg}$ adalah kurang, sedangkan dosis $3 \times 1$ kapsul yang diberikan untuk pasien pada kelompok umur 1-14 tahun sesuai menurut buku literatur Pediatric Dosage Handbook edisi 9 (2002-2003) yaitu dosis untuk bayi dan anak 8 $\mathrm{mg} / \mathrm{kg} / \mathrm{hari}$ dibagi setiap 12-24 jam, dosis maksimum $400 \mathrm{mg} /$ hari, dewasa $400 \mathrm{mg}$ /hari setiap 12-24 jam. Apabila diberikan untuk pasien dewasa dosis tersebut juga sesuai menurut buku literatur Pediatric Dosage Handbook edisi 9 (2002-2003). Sedangkan antibiotik siprofloksasin terdapat 1 pasien dengan dosis $2 \times 500 \mathrm{mg}$ untuk kelompok umur 1-14 tahun (12 tahun). Pada buku Drug Information Handbook, menyatakan bahwa dosis untuk dewasa infeksi ringan $250 \mathrm{mg}$ $2 \mathrm{x} /$ hari, infeksi berat $500-750 \mathrm{mg} 2 \mathrm{x} /$ hari, sehingga dosis yang diberikan sesuai untuk orang dewasa dan kurang sesuai untuk kelompok umur 1-14 tahun. Antibiotik sefotaksim, digunakan pada pasien kelompok umur $<1$ tahun yaitu umur 6 bulan dengan dosis yang diberikan 2x300 mg. Dalam buku Drug Information Handbook menunjukkan, dosis untuk bayi dan anak 1 bulan sampai 12 tahun adalah $50-180 \mathrm{mg} / \mathrm{kg} /$ hari dalam dosis terbagi setiap 4-6 jam. Untuk pasien dengan umur 6 bulan, dosis tersebut yang diberikan sesuai menurut buku Drug Information Handbook. 
Berdasarkan hasil penelitian dan teori, maka asumsi peneliti bahwa terjadi ketidaktepatan dosis sebanyak $(6,66 \%)$.

Tabel 5. Distribusi Tepat Cara Pemberian pada Pasien yang Terkena DBD di Ruang Rawat Inap RSI Siti Khadijah Palembang

\begin{tabular}{|c|c|c|}
\hline Tepat Cara Pemberian & Jumlah & $\begin{array}{c}\text { Persentase } \\
(\%)\end{array}$ \\
\hline Tepat & 30 & $100 \%$ \\
\hline Tidak Tepat & 0 & $0 \%$ \\
\hline Total & 30 & $100 \%$ \\
\hline
\end{tabular}

Tepat cara pemberian adalah cara mengkomsumsi obat yang tepat agar menimbulkan efek terapi, oleh karena itu sangat penting untuk memberikan cara minum obat yang baik dan benar. Berdasarkan data yang didapat, pasien diberikan secara oral dan parenteral. Untuk infus RL diberikan secara parenteral dan untuk tablet serta sirup diberikan secara oral. Berdasarkan tabel 4.5 dapat di lihat bahwa tepat cara pemberian obat sebanyak 30 orang $(100 \%)$.

Tepat cara pemberian adalah ketepatan pemilihan cara yang diberikan sesuai dengan diagnosa, kondisi pasien dan sifat obat. Misalnya peroral (melalui mulut), pervaginal (melalui vagina), perenteral (melalui suntikan, intravena, intramuscular, subkutan) atau topical (dioleskan dikulit, seperti krim, gel, salep) (Nasif dkk, 2013). Rute pemberian obat berpengaruh terhadap kecepatan efek yang akan timbul setelah penggunaan obat.

Tidak Ada penelitian terkait, karena belum ada penelitian yang sama yang pernah dilakukan dirumah sakit.

Berdasarkan hasil penelitian dan teori, maka asumsi peneliti bahwa semua cara pemberian dilakukan secara tepat (tepat 100\%).

Tabel 6. Distribusi Tepat Interval Waktu Pemberian pada Pasien yang Terkena DBD di Ruang Rawat Inap RSI Siti Khadijah Palembang

\begin{tabular}{|c|c|c|}
\hline $\begin{array}{c}\text { Tepat Interval Waktu } \\
\text { Pemberian }\end{array}$ & Jumlah & $\begin{array}{c}\text { Persentase } \\
(\%)\end{array}$ \\
\hline Tepat & 30 & $100 \%$ \\
\hline Tidak Tepat & 0 & $0 \%$ \\
\hline Total & 30 & $100 \%$ \\
\hline
\end{tabular}

Tepat interval waktu pemberian adalah aturan pakai interval waktu yang diberikan dalam mengkomsumsi obat. Tepat interval waktu dapat dilihat dicatatan rekam medik pasien yang dilihat dari jarak antara waktu obat yang diberikan dengan aturan pakai yang diminum oleh pasien.
Cara pemberian obat hendaknya dibuat sesederhana mungkin dan praktis agar mudah ditaati oleh pasien. Obat yang harus diminum $3 \mathrm{x}$ sehari harus diartikan bahwa obat tersebut harus diminum dengan interval waktu setiap 8 jam (Kemenkes,2011).

Tidak Ada penelitian terkait, karena belum ada penelitian yang sama yang pernah dilakukan dirumah sakit. Berdasarkan hasil penelitian dan teori, maka asumsi peneliti bahwa semua interval waktu pemberian dilakukan secara tepat (tepat 100\%).

Tabel 7. Distribusi Tepat Lama Pemberian pada Pasien yang Terkena DBD di Ruang Rawat Inap RSI Siti Khadijah Palembang

\begin{tabular}{|c|c|c|}
\hline Tepat Lama Pemberian & Jumlah & $\begin{array}{c}\text { Persentase } \\
(\%)\end{array}$ \\
\hline Tepat & 30 & $100 \%$ \\
\hline Tidak Tepat & 0 & $0 \%$ \\
\hline Total & 30 & $100 \%$ \\
\hline
\end{tabular}

Dari tabel diatas menunjukkan bahwa lama pemberian obat terjadi pada hari ke 5-8 hari (65\%). Sedangkan untuk 1-4 hari hanya terdapat 9 pasien (30\%), dan untuk yang $>8$ hari adalah sebanyak 4 pasien (13\%).

Tepat lama pemberian adalah agar obat dapat memberikan efek terapi yang tepat. Pemberian obat yang terlalu singkat atau terlalu lama dari yang seharusnya, akan mempengaruhi hasil pengobatan (Kemenkes,2011).

Tidak Ada penelitian terkait, karena belum ada penelitian yang sama yang pernah dilakukan dirumah sakit. Berdasarkan hasil penelitian dan teori, maka asumsi peneliti bahwa semua lama pemberian dilakukan secara tepat (tepat 100\%).

Tabel 8. Distribusi Tepat Kepatuhan Pasien pada Pasien yang Terkena DBD di Ruang Rawat Inap RSI Siti Khadijah Palembang

\begin{tabular}{|c|c|c|}
\hline Tepat Kepatuhan Pasien & Jumlah & $\begin{array}{c}\text { Persentase } \\
(\%)\end{array}$ \\
\hline Tepat & 30 & $100 \%$ \\
\hline Tidak Tepat & 0 & $0 \%$ \\
\hline Total & 30 & $100 \%$ \\
\hline
\end{tabular}

Kepatuhan pasien dapat dilihat pada catatan pemberian obat, apakah pasien lupa minum obat atau tidak. Tepat kepatuhan pasien ini telah dilakukan secara tepat $(100 \%)$. Tidak Ada penelitian terkait, karena belum ada penelitian yang sama yang pernah dilakukan dirumah sakit.

Berdasarkan hasil penelitian dan teori, maka asumsi peneliti bahwa semua kepatuhan pasien dilakukan secara tepat (tepat 100\%).

Tabel 9. Distribusi Kerasionalan Pengobatan pada Pasien yang Terkena DBD di Ruang Rawat Inap RSI Siti Khadijah Palembang

\begin{tabular}{lcc}
\hline Kerasionalan Pengobatan & Jumlah & $\begin{array}{c}\text { Persentase } \\
(\mathbf{\%})\end{array}$ \\
\hline Tepat & 28 & $93,33 \%$
\end{tabular}




\begin{tabular}{rcc}
\hline Tidak Tepat & 2 & $6,66 \%$ \\
\hline Total & 30 & $100 \%$ \\
\hline
\end{tabular}

Kerasionalan pengobatan adalah pengobatan yang tepat secara rekam medik dan memenuhi persyaratan. Pada penelitian kerasionalan pengobatan yang terjadi yaitu sebesar 93,33\%. Hal ini dikarekan adanya ketidaktepatan pada pemberian dosis, dimana dosis yang diberikan terlalu rendah atau undersoses.

Penggunaan obat yang rasional adalah apabila pasien menerima pengobatan sesuai dengan kebutuhan klinisnya, dalam dosis yang sesuai dengan kebutuhan, dalam periode waktu dan dengan biaya yang terjangkau oleh dirinya dan kebanyakan masyarakat. (WHO,2011).

\section{Kesimpulan}

1. Ketepatan pengobatan pada pasien demam berdarah dengue berdasarkan tepat diagnosis adalah sebesar $100 \%$.

2. Ketepatan pengobatan pada pasien demam berdarah dengue berdasarkan tepat indikasi adalah sebesar $100 \%$.

3. Ketepatan pengobatan pada pasien demam berdarah dengue berdasarkan tepat pemilihan obat adalah sebesar $100 \%$.

4. Ketepatan pengobatan pada pasien demam berdarah dengue berdasarkan tepat dosis adalah sebesar $90 \%$. Hal ini dikarenakan terdapat 2 status responden yang mengalami ketidaksesuaian dengan dosis.

5. Ketepatan pengobatan pada pasien demam berdarah dengue berdasarkan tepat cara pemberian adalah sebesar $100 \%$.

6. Ketepatan pengobatan pada pasien demam berdarah dengue berdasarkan tepat interval waktu pemberian adalah sebesar $100 \%$.

7. Ketepatan pengobatan pada pasien demam berdarah dengue berdasarkan tepat lama pemberian adalah sebesar $100 \%$.

8. Ketepatan pengobatan pada pasien demam berdarah dengue berdasarkan waspada terhadap efek samping adalah tidak tepat.

9. Ketepatan pengobatan pada pasien demam berdarah dengue berdasarkan kondisi penilaian pasien adalah tidak tepat.

10. Ketepatan pengobatan pada pasien demam berdarah dengue berdasarkan obat efektif, aman, mutu terjamin dan harga yang terjangkau adalah tidak tepat.

11. Ketepatan pengobatan pada pasien demam berdarah dengue berdasarkan tepat informasi adalah tidak tepat.

12. Ketepatan pengobatan pada pasien demam berdarah dengue berdasarkan tepat dalam upaya tindak lanjut adalah tidak tepat.
13. Ketepatan pengobatan pada pasien demam berdarah dengue berdasarkan tepat penyerahan obat adalah tidak tepat.

14. Ketepatan pengobatan pada pasien demam berdarah dengue berdasarkan tepat kepatuhan pasien adalah sebesar $100 \%$.

15. Ketepatan pengobatan pada pasien demam berdarah dengue adalah sebesar 93,33\%, Karena terdapat ketidaktepatan dosis dari ke-14 kriteria tersebut.

\section{Daftar Pustaka}

Akhmad, 2016. Evaluasi Penggunaan Obat Pada Pasien Demam Berdarah Dengue di RSUD DR. H. Abdul Moeloek Bandar Lampung. Jurnal. Fakultas Farmasi Universitas Gadjah Mada Yogyakarta.Albert \& Samet, 2015. At Glance Anamnesis Dan Pemeriksaan Fisik. Jakarta. Penerbit Erlangga.

Kemenkes RI, 2013. Pencegahan dan Pemberantasan Demam Berdarah. Dengue di Indonesia. Jakarta. Kemenkes RI.Kemenkes RI, 2014. Buku Pedoman Pengendalian Penyakit Paru Obstruksi Kronik. Jakarta. Kemenkes RI

Kemenkes RI, 2014. Tata Laksana Demam Berdarah Dengue di Indonesia. Jakarta. Kemenkes RI.Pustikaningtiyas, 2014. Identifikasi Drug Related Problems (DRPs) pada Pasien Penyakit Paru Obstruktif Kronik (PPOK) Rawat Inap di RS Paru Jember. Skripsi. Universitas Jember, Jawa Timur.

Notoatmodjo, 2014. Metodologi Penelitian Kesehatan Edisi Revisi. Jakarta. Rineka Cipta.Andayani, 2015. Faktor Risiko Kejadian Drug Related Problems Pada Pasien Penyakit Kronis Rawat Jalan di Poliklinik Penyakit Dalam. Jurnal. Fakultas Farmasi, Universitas Gadjah Mada, Yogyakarta

Sutiawati, 2016. Evaluasi Rasionalitas Penggunaan Obat Pada Pasien DHF (Dengue Hemorrhagic Fever) Ditinjau Dari Penggunaan Antibiotik di Rumkital (Rumah Sakit Angkatan Laut) DR. Mintohardjo Jakarta Pusat. Jurnal. Fakultas Kedokteran Dan Ilmu Kesehatan Program Studi Farmasi Jakarta.

World Health Organization, 2009., Dengue Guidelines For Diagnosis, Treatment, Prevention, And Control., WHO Press, France, pp. 3-5.

World Health Organization. 2011.
Dengue Hemorragic Fever: Dianosis,
Treatment, Prevention and Control. Edisi
keempat. Genewa: WHO Press, 9-15.


Kementrian Kesehatan

RI. 2011.

Modul Penggunaan Obat R 
1. 